\title{
Proto Language and Education of Duano Ethnic at Sabak Regency
}

\author{
Diana Rozelin* \\ Postgraduate School \\ Islamic State University of Sulthan Thaha Saifuddin \\ Jambi, Indonesia \\ *drozelin76@gmail.com
}

\author{
Mailinar \\ History of Islamic Civilization Departments, Adab and \\ Humanities Faculty \\ Islamic State University of Sulthan Thaha Saifuddin \\ Jambi, Indonesia \\ mailinar78@gmail.com
}

\author{
Ulfatmi Azlan \\ English Literature Department, Adab and Humanities \\ Faculty \\ Islamic State University of Sulthan Thaha Saifuddin \\ Jambi, Indonesia \\ ulfaazlan@gmail.com
}

\author{
Louisiana Muliawati \\ Chemistry Education Departments, Tarbiyah and Teacher \\ Training Faculty \\ Islamic State University of Sulthan Thaha Saifuddin \\ Jambi, Indonesia \\ louisiana.muliawati@gmail.com
}

\begin{abstract}
The position of Duano Isolect included to endangered language showed a shift in vocabulary. Innovations were found at young generation and relics at the older generation. This problem resulted that Duano isolect is being the second language under Malay language. The purposes of the research were to find out the proto language of Duano ethnic from Sabak, words shift, words maintenance, and to find out the ways of Duano educate their children in preserving their mother tongue in Sabak. This research is conducted in qualitative and quantitative, for collecting data used observation, interview, documentation, and recording. The results were (1) The proto language of Duano ethnic in Sabak was divided into two kinds, they were shift and maintenance. The wordlist of Swadesh (200 basic words) from four infotmants through cognate were first informant $49 \%$ data, second informant $49 \%$ data, third informant $51.5 \%$ data, and fourth informant $49.5 \%$ data. The highest maintenance or relic of proto language is found at the third informant $11 \%$; and the uppermost of shift or innovation was the first informant. She got $90 \%$ from 200 wordlist. (2) The Duano's parents used traditional education in educating their children in preserving their mother tongue. Words shift occurred because of shame, countrified, adaptation to Malay, and intermarriage.
\end{abstract}

Keywords-dialectology, education, duano, proto language

\section{INTRODUCTION}

Sabak was the rainbow place since this regency categorized as multiethnic, people from different ethnics inhabit each other, they were Javanese, Banjar, Malay, and Bugis. Besides those ethnicities, one ethnic that also lived in this area was a sea tribe person which is called Duano. This regency was unique because the assimilation of some vocabularies from those different cultures could be found in this place. In their daily communication, they used Malay language. The Duano ethnic was unique because their lexicon was quite different from other Malay. They were considered as part of Bajau people from the perspective of the local people but historically they were different. Anderbeck [1] in his writing about The Malayic Speaking Orang Laut. He found that Duano ethnic does not belong to Bajau ethnic because there are some significant differences between those ethnics. Duano people could be found along the coastal area of Sumatera Island and Malaysia. In some cases, it was found that there are similarities in vocabularies between Malay and Duano. As stated by Yusof [2] who conducted a research study in Kampung Pontian Besar, Kampung Bumiputera Dalam, and Kampung Kuala Benut, Malaysia They found that there were similarities between Duano and Malay people in the numeral system. Their interaction with the Malay people in the economic field was considered as the main factor. The population of Duano people in this area is smaller than other ethnics; they could be said as the minority group. The population of Duano in Sabak was only 100 families, the count was almost equal to the population of Duano in Tungkal. Their life was far from the prosperous. They worked as the fisherman and labor to fulfill their daily life. Meanwhile, for young people, they were accustomed to help their parents finding a side job. The number of young generation who achieved higher education was smaller than other young people at Kampung Laut. It could be concluded that Duano people had weakness economically and socially. In another case, they had their mother tongue but they prefer to use the Malay language. They felt inferior when they had to show their identity as Duano. People sometimes label them with negative views. 
The crucial problem related to their mother tongue appears since they choose Malay as their communication tool. This problem could threaten their mother tongue and for the long time effect, it could be extinct. Their next generation would not know about their ancestors and history. It was also supported by the finding of Kantor Bahasa Jambi as stated in Jambi Express Newspaper that the Duano language in Tungkal and Sabak could be categorized into endangered language. As stated by Wurm in Crystal books [3] that there are five conditions to categorize language to be safe and not safe, they are: first, potentially endangered languages: they are socially and economically disadvantaged, under heavy pressure from a larger language, and beginning to lose child speakers; second, endangered languages: have few or no children learning the language, and the youngest good speakers are young adults; third, seriously endangered languages: have the youngest good speakers age 50 or older; fourth, moribund languages: have only a handful of good speakers left, mostly very old; fifth, extinct languages: have no speakers left.

Generally, many factors contributed to this situation such as intermarriage, natural disaster, migration, etc. For the Duano people, intermarriage was the strongest factor because the majority of people of Duano marry the people outside of their community. The children who grow up in this family were taught Malay than their dialect. Language habits must start early. Early childhood education greatly affects a child's language. Habits in behavior and attitudes would also affect the habits of children after adulthood. The habits of children at home will also affect the habits of children at school. For example, the speed of learning toilet training in early childhood depends on the habits of the child at home [4]. Therefore, to get children used to speaking properly and correctly, children's independence must be trained from an early age. The values of independence of children aged 3-4 years were more independent and able to carry out daily activities. Besides, children were more responsible for their duties. This child's independence ability must be trained from an early age [5]

This writing tried to investigate the maintenance of their proto-language and the assimilation that occurs in this area. The assimilation itself did not only occur in the language but also communication [6]. So, this research did not only analyze dialectology but also communication between them. It was also aimed to find out the ways of Duano's parents in educating their children in preserving their mother tongue.

\section{METHODS}

There were two types of research used in this study: qualitative and quantitative. These two kinds of research were used alternately. In the initial stage, qualitative research was used to describe the data related to lexical and phonological data. In the next stage, the result of observation would be tested first in quantitative research by applying the dialectometry formula, Ayatrohaedi [7]. Quantitative research used the dialectometry technique to determine:

$$
\frac{(\mathrm{S} \times 100)}{\mathrm{N}}=\mathrm{D} \%
$$

Description:

$\mathrm{S}=$ the number lexicon that is different from another area

$\mathrm{N}=$ number of maps to be compared

$\mathrm{D}=$ distance vocabulary in percentage

Lincoln in Muhammad [8] said that qualitative research was multi-method in focus, involving an interpretive, naturalistic approach to its subject matter. It means that qualitative research studies in their natural setting, attempting to make sense of or interpret phenomena in terms of the meanings that people bring to them. The instrument of this study was the Basic Austronesian Wordlist that consists of 200 words. This instrument was written by Blust, R.A. 1981, in his paper: Variation in retention Rate among Austronesian Languages. This study used 4 informants, from one villageKampung Laut. Spradley in Moleong [9] said that the informant was a king because he was a person who helped the researcher to get the data. Before conducting the interviews, the researcher provides an overview of the informant about the research and what to look for, so that the informant knows what was desired by the researcher. Chambers dan Trudgill [10] said the majority of informants had in all cases consisted of non-mobile, older, and rural males. Muhammad [8] explained the requirements: 1) male and female, 2) the age is around 25 - 65 years (not senile), 3) have pride to their isolect, 4) fluent in the Indonesian language, in this research the priority for those who understand about Malay Jambi dialect, 5) physically and mentally healthy.

Selected informants were community members who lived in Kampung Laut village at Sabak. The researchers choose informants based on the requirements that had been mentioned above. In choosing the informants, this study used a purposive sampling technique. Meanwhile, in collecting the data, the technique is used as proposed by Miles and Huberman [11], they are: interactive and non-interactive. The interactive method was done through interviews and observation, so interviews and observation were chosen as the techniques of this study. In the analysis of data, this study used the comparative method. Then, the technique has used the technique of comparative equalize circuit (HBS), the appeal circuit techniques to distinguish (HBB) and circuit techniques equate appeal subject matter (HBSP) [12]. The technique is used to analyze phonemes, lexicon, and morpheme. Besides that, this study also used descriptive techniques to describe the assimilation, shift words, and education development in nuclear families.

This research focused on relic and maintenance of Duano words viewed from Proto language, the development of their children education especially at the using language at their nuclear family, and assimilation at words and culture. 


\section{RESULTS AND DISCUSSION}

The proto-language was divided into two kinds, they were shift and maintenance. The wordlist of Swadesh (200 basic words) from four informants through cognate, they are Anisa 49\% data, Harun $49 \%$ data, Asri $51.5 \%$ data, and Nur $49.5 \%$ data. The highest maintenance of proto-language is found at the third informant Asri Tara (Temenggung) 11\%, and the highest of innovation or shift of proto-language of Duano ethnic was Anisa. She got $90 \%$ from 200 wordlists. The population of Duano society was 70 families; 30 families had done intermarriage with Banjar, Bugis, Palembang, and Malay. They did not speak Duano with their children because they feel inferior, they did not understand, and they did adapt to Malay people.

Word shift or innovation word was the word that differs from the proto-language. The difference did not only occur at one syllable but also two, three, or one word. The first informant-Anisa got 180 words, Harun and Nur Tekong got 179 words, and Asri Tara got 178 words. It meant that the percentage of word shift of Anisa was highest than Asri Tara. The example of words shift can be seen in Table 1 .

TABLE I. DATA OF WORDS SHIFT

\begin{tabular}{|l|l|l|l|l|l|l|}
\hline No. & Malayo-Polynesia & \multicolumn{1}{|c|}{ Bahasa Indonesia } & \multicolumn{1}{c|}{$\begin{array}{c}\text { Anisa } \\
\text { I }\end{array}$} & $\begin{array}{c}\text { Harun } \\
\text { II }\end{array}$ & $\begin{array}{c}\text { Asri.T } \\
\text { III }\end{array}$ & $\begin{array}{c}\text { Nur. T } \\
\text { IV }\end{array}$ \\
\hline 1. & esa/isa & SATU & {$[$ siko?] } & {$[$ siko?] } & {$[$ siko?] } & {$[$ siko?] } \\
\hline 2. & i-sai & SIAPA & {$[$ kuasan] $]$} & {$[$ kuasan] } & {$[$ kuasay $]$} & {$[$ siapo] } \\
\hline 3. & p-ijan & KAPAN & {$[$ kapan $]$} & {$[$ kapan] } & {$[$ kapan] } & {$[$ komolo] } \\
\hline
\end{tabular}

The examples above showed the differenciate in sylabel. Datum gloss SATU (no.1), PM *esa/isa experiencing the same innovation at informants I, II, III, and IV as [siko?], it difference at 4 syllables. Innovation at PM *esa/isa > [siko?] was found at informants I, II, III, IV. Apheresis occured at the beginning of the word; phoneme changes $* / \mathrm{s} />/ \mathrm{k} / ; * / \mathrm{a} />/ \mathrm{o} /$; and apokope at the end of the word $* / \varnothing />/ ? /$.

Datum gloss SIAPA (no.2), PM *i-sai $>$ [kuasan] was found at informants I, II, III and the word [siapə] was found at informant 4, it difference at 4 syllables. Apheresis occured at the beginning of the word; phoneme changed $* / \varnothing />/ \mathrm{k} / ; * / \varnothing />$ $/ \mathrm{u} /$; sinkope at the middle of the word $* / \mathrm{i} />/ \mathrm{a} /$; and apokope at the end of the word $* / \mathrm{i} />/ \mathrm{y} /$.

Datum gloss KAPAN (no.3), PM *p-ijan > [kapan] was found at informants I, II, III, it difference at 3 syllables. The word [komolo] was found at informant 4, it difference at 6 syllables. The phoneme $* / \mathrm{p} />/ \mathrm{k} / ; * / \mathrm{i} />/ \mathrm{a} / ; * / \mathrm{s} />/ \mathrm{p} /$. The phoneme [komolo] $* / \mathrm{p} />/ \mathrm{k} / ; * / \mathrm{i} />/ \mathrm{o} / ; * / \mathrm{s} />/ \mathrm{m} / ; * / \mathrm{a} />/ \mathrm{o} /$; $* / \mathrm{n} />/ 1 /$, and apokope at the end of the word $* / \varnothing />/ \mathrm{o} /$.

Datum gloss MALAM (no.4), PM *beRpi > [boren] was found at informants I, II, III, it difference at 3 syllables. The word [berem] was found at informant 4 , it difference at 3 syllables. The phoneme $* / \mathrm{e} />/ \mathrm{\partial} / ; * / \mathrm{y} />/ \mathrm{e} / ; * / \mathrm{i} />/ \mathrm{y} /$. The phoneme $[$ berem] $* / \mathrm{y} />/ \mathrm{e} / ; * / \mathrm{i} />/ \mathrm{m} /$.

Datum gloss KIRI (no.5), PM *ka-wiRi > [kiRl] was found at all of informants I, II, III, and IV it difference at 2 syllables. The phoneme $* / \mathrm{a} />/ \varnothing / ; * / \mathrm{w} />/ \varnothing /$; as sinkope.

Datum gloss KAKI (no.6), PM * qaqay > [tepu] was found at informants I, II, it difference at 5 syllables. The word [kaki] was found at informant III, IV, it difference at 4 syllables. The phoneme [tepu $\}$ changed $* / \mathrm{q} />/ \mathrm{t} / ; * / \mathrm{a} />/ \mathrm{e} / ; * / \mathrm{q} />/ \mathrm{p} / ; * / \mathrm{a} />$ $/ \mathrm{u} /$; and apakope at the end of syllabel $* / \mathrm{y} />/ \varnothing /$. The phoneme [kaki] changed $* / \mathrm{q} />/ \mathrm{k} / ; * / \mathrm{a} />/ \mathrm{i} /$; and apakope at the end of syllabel $* / y />/ \varnothing /$.
Data gloss KOTOR (no.8), PM *cemeD? > [kotor] was found at informants I, II, III, IV, it difference at 6 syllables. The phoneme [kotor ] changes $* / \mathrm{c} />/ \mathrm{k} / ; * / \mathrm{e} />/ \mathrm{o} / ; * / \mathrm{m} />/ \mathrm{t} /$; $* / \mathrm{D} />/ \varnothing /$ as sinkope at the middle word; and $* / ? />/ \mathrm{R} /$.

Datum gloss PERUT (no.9), PM *tian > [bətEn] was found at informants I, II, III it difference at 5 syllables. The word [perひt] was found at informant IV, it difference at 5 syllables. The phoneme [bətEn] changed $* / \mathrm{t} />/ \mathrm{b} / ; * / \mathrm{i} />/ \mathrm{\partial} / ; * / \varnothing />/ \mathrm{t} /$ as epentesis, it was adding syllabel at middle word; $* / \mathrm{a} />/ \mathcal{E} /$; and $* / \mathrm{n} />/ \mathrm{y} /$. The phoneme [perర̈t] changed $* / \mathrm{t} />/ \mathrm{p} / ; * / \mathrm{i} />/ \mathrm{e} / ;$ $* / \varnothing />/ \mathrm{r} /$ as epentesis, it is adding syllabel at middle word; */a/ $>/ \widetilde{J} /$; and $* / \mathrm{n} />/ \mathrm{t} /$.

The examples below (Table 2) were the words that still used by Duano ethnic and those words were the same with Proto Malay. The examples below were divided into two groups. The first, the maintain words that were used by all of the informants. The second, the maintain words that were used by some of the informants.

TABLE II. THE WORDS MAINTAIN

\begin{tabular}{|l|l|l|l|l|l|l|}
\hline No. & $\begin{array}{c}\text { Malayo- } \\
\text { Polynesia }\end{array}$ & $\begin{array}{c}\text { Bahasa } \\
\text { Indonesia }\end{array}$ & $\begin{array}{c}\text { Anisa } \\
\text { I }\end{array}$ & $\begin{array}{c}\text { Harun } \\
\text { II }\end{array}$ & $\begin{array}{r}\text { Asri.T } \\
\text { III }\end{array}$ & $\begin{array}{c}\text { Nur.T } \\
\text { IV }\end{array}$ \\
\hline 1. & kulit & KULIT & {$[$ kulit $]$} & {$[$ kulit $]$} & {$[$ kulit $]$} & {$[$ kulit $]$} \\
\hline 2. & susu & SUSU & {$[$ susu $]$} & {$[$ susu $]$} & {$[$ susu $]$} & {$[$ susu $]$} \\
\hline 3. & qulu & KEPALA & {$[$ qulu $]$} & {$[$ qulu $]$} & {$[$ qulu $]$} & {$[$ qulu $]$} \\
\hline
\end{tabular}

Datum gloss KULIT (no.1), PM *kulit > [kulit] was found at informants I, II, III, IV. There was no syllabel changing in that word. It meant the people of Duano still maintain their ancestor's word.

Datum gloss SUSU (no.2), PM * susu > [susu] was used by informants I, II, III, IV. There was no syllabel changing between the word of PM and the word of Duano ethnic. 
Datum gloss KEPALA (no.3), PM *qulu > [qulu] was used by informants I, II, III, IV. There was no syllabel changing in that word. All the informants used the same word.

Datum gloss BELI (no.4), PM *beli > [beli] was used by informants I, II, III, IV. All the informants used the same word in their daily communication.

Datum gloss BULU (no.5), PM *bulu > [bulu] was used by informants I, II, III, IV. There was no syllabel changing in that word. It meant the people of Duano still maintain their ancestor's word.

Datum gloss KUTU (no.6), PM *kutu > [kutu] was used by informants I, II, and III. There is no syllabel changing in that word. Data gloss PM *kutu > [tup] was used by informant IV; it means there was relic and innovation at that word.

Datum gloss BUNGA (no.7), PM *buya $>$ [buya] was used by informants I, II, and III. There was no syllabel changing in that word. Data gloss PM *buna $>$ [buno] was used by informant IV; it meant there was innovation or shift at that word, $* / \mathrm{a} />/ \mathrm{o} /$.

Datum gloss MATA (no.8), PM *mata > [mata] was used by informants IV. There was no syllabel changing in that word. Data gloss PM *mata > [matu] was used by informant I, II, III; it meant there was innovation or shift at that word, $* / \mathrm{a} />/ \mathrm{u} / \mathrm{at}$ ultima final.

Datum gloss BULAN (no.9), PM *bulan > [bulan] was used by informants I, II,III, IV. There was no syllabel changing in that word. All the informants used the same word.

Datum gloss INI (no.10), PM *i-ni > [ini] was used by informants I, II,III, IV. There was no syllabel changing in that word, it meant Duano ethnic still maintain their ancestor word.

Datum gloss BULU (no.11), PM *bulu > [bulu] was used by informants I, II,III, IV. There is no syllabel changing in that word, all of the informants from Duano ethnic used the same word.

Based on all of the data 200 wordlist for each informant, showed that words relic or words maintain are not much. The highest relic just 22 words, that found at Asri Tara. The data showed that much of Duano ethnic used Malay words in doing communication than used their own words. Table 3 shows the count of cognate and maintain words.

TABLE III. THE CALCULATION OF COGNATE AND MAINTAIN

\begin{tabular}{|c|l|l|l|l|}
\hline NO & $\begin{array}{c}\text { Informant } \\
\text { I }\end{array}$ & $\begin{array}{c}\text { Informant } \\
\text { II }\end{array}$ & $\begin{array}{c}\text { Informant } \\
\text { III }\end{array}$ & $\begin{array}{c}\text { Informant } \\
\text { IV }\end{array}$ \\
\hline \multirow{2}{*}{ Cognate } & 98 & 98 & 103 & 99 \\
\cline { 2 - 5 } & $49 \%$ & $49 \%$ & $51.5 \%$ & $49.5 \%$ \\
\hline \multirow{2}{*}{ Maintain } & 20 & 21 & 22 & 21 \\
\cline { 2 - 5 } & $10 \%$ & $10.5 \%$ & $11 \%$ & $10.5 \%$ \\
\hline
\end{tabular}

Ages is one of the point that can change the rules of development of the language. Anisa is the younger informant from all of informants; Harun and Nur Tekong have the same age, and Asri Tara is the older than others.

TABLE IV. PHONOLOGY INNOVATION FROM PM-DUANO AT SABAK

\begin{tabular}{|c|c|c|c|}
\hline NO & PM & DUANO & TOTAL \\
\hline 1 & $*_{\mathrm{S}}$ & $\mathrm{k}, \mathrm{p}, \mathrm{m}, \mathrm{b}, \mathrm{n}, \mathrm{l}, \varnothing$ & 7 \\
\hline 2 & $* \mathrm{a}$ & $\mathrm{o}, \varnothing, \mathrm{e}, \mathrm{u}, \mathrm{i}, \partial, \mathcal{E}, \widetilde{J}, \mathrm{~J}, \mathrm{~g}$ & 10 \\
\hline 3 & $* \varnothing$ & $?, \mathrm{k}, \mathrm{u}, \mathrm{o}, \mathrm{t}, \mathrm{r}, \mathrm{r}, \mathrm{n}, \mathrm{l}, \mathrm{y}, \mathrm{a}, \mathrm{i}, \mathrm{b}, \mathrm{e}, \mathrm{m}, \mathrm{s}, \mathrm{j}, \mathrm{p}$ & 18 \\
\hline 4 & $*_{\mathrm{i}}$ & $\mathrm{a}, \mathrm{\eta}, \mathrm{o}, \mathrm{m}, ə, \mathrm{e}, \mathrm{u}, \mathcal{E}, \varnothing, \mathrm{n}$ & 10 \\
\hline 5 & $* \mathrm{p}$ & $\mathrm{k}, \mathrm{b}, \mathrm{w}, \mathrm{m}, \mathrm{s}, \mathrm{n}$ & 6 \\
\hline 6 & $* n$ & $1, \mathrm{n}, \mathrm{t}, \mathrm{j}, \mathrm{b}, \mathrm{m}, \varnothing, ?, \mathrm{R}, \mathrm{o}, \mathrm{k}, \mathrm{y}, \mathrm{s}, \mathrm{r}$ & 14 \\
\hline 7 & $* \mathrm{e}$ & $\partial, \mathrm{o}, \varnothing, \mathrm{i}, \mathrm{a}, \mathrm{u}$ & 6 \\
\hline 8 & $* \eta$ & $\mathrm{e}, \mathrm{k}, \mathrm{R}, \varnothing, \mathrm{n}$ & 5 \\
\hline 9 & $*_{\mathrm{W}}$ & $\varnothing, 1, \mathrm{~s}, \mathrm{y}, \mathrm{u}, \mathrm{b}, \mathrm{y}, \mathrm{h}$ & 8 \\
\hline 10 & $* \mathrm{q}$ & $\mathrm{t}, \mathrm{p}, \mathrm{k}, \varnothing, \mathrm{h}, \mathrm{\eta}, \mathrm{s}, \mathrm{b}, \mathrm{r}, ?$ & 10 \\
\hline 11 & $* \mathrm{y}$ & $\varnothing, \mathrm{i}, \mathrm{t}, \mathrm{r}, \mathrm{R}$ & 5 \\
\hline 12 & $*_{\mathrm{Z}}$ & $\mathrm{j}, \mathrm{d}, \mathrm{m}$ & 3 \\
\hline 13 & $* \mathrm{c}$ & $\mathrm{k}$ & 1 \\
\hline 14 & $* \mathrm{~m}$ & $\mathrm{t}, \varnothing, \mathrm{R}, \mathrm{n}, \mathrm{n}, \mathrm{\eta}, 1$ & 7 \\
\hline 15 & $* \mathrm{D}$ & $\varnothing$ & 1 \\
\hline 16 & $* ?$ & $\mathrm{R}, \mathrm{m}, \mathrm{n}$ & 3 \\
\hline 17 & $* \mathrm{t}$ & $\mathrm{b}, \mathrm{p}, \mathrm{k}, \mathrm{l}, \varnothing, \mathrm{d}, \mathrm{s}, \mathrm{m}, \mathrm{n}, \mathrm{r}, ?, \mathrm{n}, \mathrm{g}$ & 13 \\
\hline 18 & $*_{\mathrm{R}}$ & $\mathrm{h}, \mathrm{y}, \mathrm{g}, \mathrm{b}, \varnothing$ & 5 \\
\hline 19 & $*_{\mathrm{k}}$ & $\mathrm{b}, \mathrm{t}, \mathrm{i}, ?, \varnothing, \mathrm{m}, \mathrm{s}, \mathrm{g}, \mathrm{l}, \mathrm{c}, \mathrm{R}$ & 11 \\
\hline 20 & $*_{\mathrm{u}}$ & e,o,a,i,Ø,つ & 6 \\
\hline 21 & $* b$ & $\mathrm{n}, \mathrm{r}, \mathrm{m}, \mathrm{l}, \mathrm{p}, \mathrm{d}, \mathrm{u}, \mathrm{t}, \mathrm{k}, \mathrm{w}, \varnothing, \mathrm{n}$ & 12 \\
\hline 22 & $* 1$ & $\mathrm{R}, \mathrm{b}, \mathrm{i}, \mathrm{m}, \mathrm{d}, \mathrm{k}, \mathrm{t}, \mathrm{c}, \mathrm{g}$ & 9 \\
\hline 23 & $* d$ & $\mathrm{n}, \mathrm{n}, \mathrm{p}, \mathrm{k}, \mathrm{l}, \mathrm{r}, \mathrm{m}, \mathrm{b}, \varnothing$ & 9 \\
\hline 24 & $* g$ & $\emptyset, \mathrm{t}, \mathrm{R}, \mathrm{h}, \mathrm{s}$ & 5 \\
\hline 25 & $* \mathrm{~h}$ & $\mathrm{t}, \mathrm{c}, \mathrm{k}, \mathrm{m}, \mathrm{b}, \mathrm{y}, \mathrm{g}, \mathrm{\eta}, \varnothing$ & 9 \\
\hline 26 & $* \mathrm{j}$ & $\mathrm{y}, \varnothing, \mathrm{m}, \mathrm{p}$ & 4 \\
\hline 27 & $* \mathrm{n}$ & $\mathrm{f}, \mathrm{t}$ & 2 \\
\hline 28 & $* \mathrm{r}$ & $\mathrm{n}, \varnothing$ & 2 \\
\hline
\end{tabular}

From the table 4 could be seen that sound changed from PM to Duano consist of 28 points. One syllable of proto changed to be 2 until 18 syllables. This change showed a fairly strong syllable changed from the Proto Malayic to Duano isolect.

For assimilation, it did not only occur at language but also a culture. Assimilation in linguistic terms meant a process of sound change that causes it to be similar or similar to other sounds that were nearby, such as-in the Indonesian language the word [sabtu] becomes [saptu]. The syllable of $b>p$; or in phonology cased mean $/ \mathrm{b} /$ and $/ \mathrm{p} /$ in the same place of articulation of bilabial. Based on 800 words, it was found that two groups that were categorized in the same place of articulation were glottal and velar. Glottal articulation $\mathrm{q}>\mathrm{h}$ can be found at number $23,25,32,35,36,38,61,74,80,85,113$, 117,147 , and 169 . Then, at velar articulation $\mathrm{k}>\mathrm{g}$ at number 90. This assimilation occurs at four informants but sometimes just occurs at 1 or 2 informants. The table 5 explain the phenomenon. 
TABLE V. ASSIMILATION AT DUANO ETHNIC

\begin{tabular}{|c|c|c|c|c|c|}
\hline PM & SYLLABLE & I & II & III & IV \\
\hline *daRaq & \multirow{15}{*}{$\begin{array}{l}\text { Glottal } \\
q>h\end{array}$} & [daRah] & [daRah] & [darah] & [daRah] \\
\hline *liqeR & & [temoron] & [temoron] & [leher] & [leher] \\
\hline$*$ dilaq/hema & & [lidah] & [lidah] & [lidah] & [lidah] \\
\hline *utaq & & [muntah] & [muntah] & [muntah] & [muntah] \\
\hline *luzaq & & [məludah] & [məludah] & [məludah] & [meludah] \\
\hline *mamaq & & [yunah] & [yunah] & [kuyah] & [yunah] \\
\hline *Rumaq & & [bonu & [bonu] & [bonu] & [umah] \\
\hline *bunuq & & [bunuh\} & [bunuh] & [bunu] & [bunuh] \\
\hline *laq/silaq & & [belah] & [belah] & [belah] & [belah] \\
\hline *piliq & & [pilih] & [pilih] & [milih] & [piloh] \\
\hline *daqan & & [dahan] & [dahan] & [dahan] & [pohon] \\
\hline *buaq & & [buah] & [buah] & [buah] & [buah] \\
\hline *ma-qitem & & [hitam] & [hitam] & [hitam] & [hitam] \\
\hline *zaqat & & [jahat] & [jahat] & [jahat] & [jahat] \\
\hline *taqun & & {$[\operatorname{tah} \sigma n]$} & [tahon] & [tahర̄n] & [tahర̄n] \\
\hline *kali & Velar k > g & [gali] & [gali] & [gali] & [gali] \\
\hline
\end{tabular}

Data number 1 until 15 include to glottal, $\mathrm{q}>\mathrm{h}$ sometimes occur at the first, second, third informants but sometimes occur only at the fourth informant. PM *daRaq; $\mathrm{q}>\mathrm{h}$-[daRah] the changes of assimilation occur at all of informants at final ultima. Glottal $\mathrm{q}>\mathrm{h}$ at number 2; PM * liqeR occurred at the third and the fourth informants. The changed of syllable at penultima of the word. The changed of syllable glottal $q>h$ that occurred at final ultima and for all of the informants found at number $32,35,36,38,80,85$, and 117 .

Data number 32 PM *dilaq/hema > Kampung Laut [lidah] at I, II, III, IV informants. The change of syllable $* \mathrm{q}>\mathrm{h}$ at final ultima for all of the informants meant there was assimilation at the final word. This phenomenon not only occurred at the final ultima but also at penultima, for example at number 25,113 , 165 , and 169 .

Data number $25 \mathrm{PM} *$ liqeR > Kampung Laut [leher] occurs at III and IV informants. The word PM *liqeR $>* \mathrm{q}>\mathrm{h}$, meant that word included to differ in phonology. Data PM *liqeR > Kampung Laut [temoron] that occurred at I, II informants had six different in syllable $*^{*}>\mathrm{t} ; *_{\mathrm{i}}>\mathrm{e} ;{ }^{*} \mathrm{q}>\mathrm{m} ;{ }^{*} \mathrm{e}>0 ; \varnothing>0 ; \varnothing>\mathrm{n}$, meant that word included to differ in lexical.

Data number 113 PM *daqan > Kampung Laut [dahan] occurs at I, II, and III informants. The word PM *daqan > Kampung Laut [dahan] had one difference in syllable $* \mathrm{q}>\mathrm{h}$, which means that word included differ in phonology. Data PM *daqan > Kampung Laut [pohon] that occurred at IV informant had four different in syllable $* \mathrm{~d}>\mathrm{p} ; * \mathrm{a}>\mathrm{o} ; * \mathrm{q}>\mathrm{h} ; * \mathrm{a}>\mathrm{o}$, meant that word included to differ in lexical.

Data number 165 PM *zaqat > Kampung Laut [jahat] occurs at I, II, III, and IV informants. The word PM *zaqat > Kampung Laut [jahat] had two differences in syllable $*_{\mathrm{Z}}>\mathrm{j}$; $* \mathrm{q}>\mathrm{h}$, which meant that word included differ in phonology. This example included penultima.

Data number 169 PM *taqun > Kampung Laut [tahひn] occurs at I, II, III, and IV informants. The word PM *taqun > Kampung Laut [tah $\widetilde{N}$ ] had one difference in syllable $* \mathrm{q}>\mathrm{h}$, which means that word included to differ in phonology. This example included penultima.

Data number 90 PM *kali > Kampung Laut [gali] occurred at I, II, III, and IV informants. The place of articulation was velar. The word PM *kali > Kampung Laut [gali] had one difference in syllable $* \mathrm{k}>\mathrm{g}$, which meant that word included differ in phonology. This example included antepenultima.

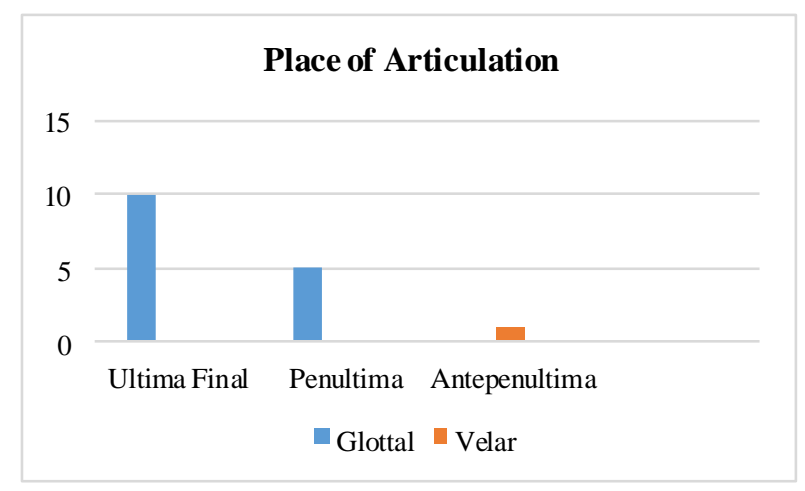

Fig. 1. The place of articulation.

Figure 1 shows that the data Kampung Laut includes to ultima final are $23,32,35,36,38,61,74,80,85,117$; all of it 10 data. The data that include to penultima are: $25,113,147$, 165,169 ; all of it 5 data, and one datum number 90 includes to antepenultima.

Assimilation in culture could be seen through the celebration of Sumbun tradition. Sumbun was one of Duano's tradition; it looked like ceremonial dancing in looking for kerang buluh. In the past, people who contributed to dance were women and the men were fishing. Sumbun could be found at low tide where the sea level became land or a small island. It was found only in three regions, they were China, Kalimantan Province, and Jambi Province.

The point of assimilation here was the dancers of Sumbun were usually performed by Duano people, but nowadays it was learned by Malay, Banjar, and Bugis people. This situation 
made Duano ethnic felt disappointed because it was their tradition but they cannot perform it by themselves. As stated by Asri Tara that sumbun was the symbol of their tradition they had more right to dance with others. But it was proof that through this multicultural society, they had adopted a certain culture with them in terms of language and ritual.

Related to the Duano dialect, it was found that Duano parents do not educate their children to preserve their mother tongue. This situation was not only occurring at Astri Tara as chieftain but also to Nisa- the young mother (35 years old). It occurred because of shame, plebeians, and intermarriage. Feeling shame when they wanted to talk Duano language. The society at that village tends to speak Malay than other dialects in the public area. So, they were not self-confident speaking Duano although with fellow ethnic of Duano. As a minority, it would be comfortable using the majority language. The statement-language showed who you wee, its description suitable for someone who speaking Duano. Duano's language was a reflection of poverty, low education, and fishermen. Intermarriages were also found at Duano ethnic, with Malay, Banjar, Palembang, and Kuala Enok. This situation made the nuclear family must choose which language be used in their family. Dominant character in a family would choose a language or dialect with their children.

\section{CONCLUSION}

The wordlist of Swadesh (200 basic words) from four informants through cognate are Anisa 49\% data, Harun 49\% data, Asri $51.5 \%$ data, and Nur $49.5 \%$ data. It Meant the data that closed to PM was Astri 51.5\%-103 data. The highest maintenance or relic of proto-language would be found at the third informant Asri 11\%, and the highest of shift or innovation of proto-language of Duano ethnic was Anisa. She got $90 \%$ from 200 wordlists. The syllables that changed from PM to Duano's words were 28 syllables.

The assimilation of Duano ethnic in Sabak consists of language and culture. The assimilation of language was found in two groups that included in the same place of articulation, they were glottal and velar. Then, at velar articulation $\mathrm{k}>\mathrm{g}$ at number 90. The assimilation words of Duano also could be found in three positions, such as antepenultima 1 datum, penultima 5 data, and ultima final 10 data. There was no assimilation of culture, but there was a changing of dancers of Sumbun, not from Duano people but Malay people. Duano parents did not educate their children in preserving their mother tongue. This situation occurred because of feeling shame, plebeian, adaptation to the Malay language, and intermarriage.

\section{ACKNOWLEDGMENT}

This research is field research assisted by several informants. Therefore, the authors would like to express their deepest gratitude and appreciation to all informants. The authors also said gratitude and high appreciation to the Chancellor of the Islamic State University of Sulthan Thaha Saifuddin Jambi and all contributors who actively participated in this research. Hopefully, this research could provide positive benefits and contributions to Linguistics and education field. Recommendation for another researcher who wants to analyze Duano community: could analyze about the extent to which the government pays attention to health, employment, and education for the duano tribe.

\section{REFERENCES}

[1] K. Anderbeck, "The Malayic-Speaking Orang Laut: Dialects and Directions for Research," Wacana, vol. 14, no. 2, pp. 265-312, 2012.

[2] R.M. Yusof and N.H.M. Suleiman, "Sistem Bilangan Dalam Bahasa Orang Asli Duano,” J. Bhs., vol. 14, no. 1, pp. 45-59, 2014.

[3] D. Crystal, Language death. Ernst Klett Sprachen, 2000.

[4] M. Munjiati, A. Fitriyani, and W. Walin, "The Effect of Disposable Water (Diaper) Usage Toward Toilet Training Behavior In Pre-School Children," KEMAS J. Kesehat. Masy., vol. 13, no. 2, pp. 145-151, 2017.

[5] D. Widianti, P. Purwadi, and I. Khasanah, "Nilai-Nilai Kemandirian Anak Melalui Scaffolding Pad Usia 3-4 Tahun Di Kelompok Bermain Paud Taman Belia Candi Semarang," PAUDIA J. Penelit. dalam Bid. Pendidik. Anak Usia Dini, vol. 8, no. 1, 2019.

[6] D. Rozelin and U. Azlan, "Proto Malayic Reflection at Isolect of Malay Jambi Seberang and Malay Sabak at Jambi Province," 2019.

[7] Ayatrohaedi, Dialektologi Sebuah Pengantar. Jakarta: Pusat Pembinaan dan Pengembangan Bahasa Departemen Pendidikan dan Kebudayaan, 1993.

[8] Muhammad, Metode Penulisan Bahasa. Yogyakarta: Ar-Ruzz Media, 2011.

[9] L.J. Moleong, "Metodologi Penelitian Kualitatif. Bandung: PT Remaja Rosdakarya..(2009)," Metodol. Penelit. kualitatif (edisi revisi), 2004.

[10] J.K. Chambers and P. Trudgill, Dialectology. Cambridge University Press, 1998.

[11] M.B. Miles and A.M. Huberman, "Qualitative Data Analysis, Diterjemahkan Oleh Tjetjep Rohendi Rohidi," Anal. Data Kualitatif, 1992.

[12] M.S. Mahsun, Dialektologi diakronis: sebuah pengantar. Gadjah Mada University Press, 1995. 